\title{
Countermeasures for the Training of Applied Talents in Colleges and Universities under the Background of Industrial Transformation and Upgrading
}

\author{
Wang Mingming ${ }^{1,}$ a; Zhao Jinfeng ${ }^{2}$ \\ ${ }^{1,2}$ School of Shandong Xiehe University, Jinan250109, China \\ a476398949@qq.com
}

\begin{abstract}
The main purpose of this paper is to explain the training strategy of applied talents in colleges and universities under the background of industrial transformation and upgrading. This paper uses the methods of literature analysis, comparative study and interview. Literature method and comparative method is used to learn the advanced experience of cultivating applied talents. Interview and comprehensive analysis are used to analyze China's economic development and industrial transformation and upgrading of regional background. This paper finds relationship between university development and industrial development through research, suggests implementing industrial restructuring and upgrading strategy, and provides new opportunities and challenges for the cultivation of applied talents in Colleges and universities. Therefore, in the background of industrial transformation and upgrading, adjusting the layout of disciplines, integrating application-oriented education system, innovating the model of talents cultivation, constructing the special combination of the teaching team and improving teaching quality guarantee system are effective countermeasures for university personnel training on the basis of industrial development.
\end{abstract}

Keywords-Universities; Industrial transformation and upgrading; Practical personnel; Personnel training countermeasures

\section{RELYING ON INDUSTRIAL TRANSFORMATION AND UPGRADING, ADJUSTING THE LAYOUT OF DISCIPLINE AND SPECIALTY}

The optimization and upgrading of industrial structure, technical structure and employment structure will inevitably bring about changes in Colleges and universities should take the initiative to adapt to the development of regional industry, with the development of industry demand, establish the norm of professional research system, starting from its own orientation and actual conditions, sufficient research, careful argumentation, planning of disciplines construction of scientific and reasonable.
Colleges and universities should take the demand of industrial transformation and upgrading as the guidance, and gradually realize the high precision docking of professional construction and regional talent market. Universities should first establish specialized adjustment planning institutions to ensure sustainable development of majors, and on the other hand, we should set up professional structure adjustment and optimization mechanism, mainly from aspects of professional development planning, professional admittance, professional assessment and professional adjustment. In the professional research and demonstration, the optimization of specialty structure adjustment, professional connotation construction links such as the introduction of the development of regional economy and industrial upgrading of the elements, let the academic experts, university social industry experts to participate in the specialty construction, multi power absorbing economic industry and the construction of professional, scientific and reasonable. Thirdly, we should integrate and optimize the resources, and finally build a new mechanism to promote the sustainable development of the professional construction of colleges and universities

\section{BASED ON THE NEEDS OF TALENTS IN INDUSTRIAL}

\section{TRANSFORMATION AND UPGRADING, IMPROVE EDUCATION} INTEGRATION AND EDUCATING MECHANISM

Colleges and universities are an important place for the training of applied talents. By training high quality applied talents, it has played a great role in promoting economic development and industrial development. In the background of industrial transformation and upgrading, the industry must be based on the development of the industry layout, with industrial transformation and upgrading of the requirements of talents, improve the education mechanism of the integration of production and education, the teaching and the actual production of organic integration, so as to improve the appropriateness of personnel training, to further promote the economic development. 


\section{A. Constructing the management mechanism of education integration and educating people}

The integration of production and education is mainly about the integration of production and education, the development of education, embodied in the effective combination of education, research and production, the close combination of theory and practice, and the organic combination of education and production in three aspects. First, to realize the integration and education of production and education, the emphasis should be on the construction of the dynamic mechanism of the integration and educating people. Consistency which continued to improve scientific research institutes, universities and enterprises internal interests and development direction, to promote college talent cultivation to produce high quality product quality, enterprises and research institutes, improving their competitiveness, promote the main parties to play their own initiative, complementary advantages, to achieve their own goals and development needs. Second, strengthen the management system of cooperative education. The integration of production and education constituted by different subjects so that the interests of all parties is particularly important coordination through the corresponding system, including the establishment of leadership, responsibility and rights constraints and rules of teaching and scientific research, production, marketing and other aspects of the transformation, clear the main interests of all risks, safeguard the rights and interests of the subjects each, to achieve the integration of production and education educating people.

\section{B. Perfect the ways of education and educating people}

In order to improve the integration of production, education and education, colleges and universities can mainly start from perfecting production and teaching practice bases, establishing laboratory jointly by schools and enterprises, establishing cooperation between schools and enterprises, building engineering and technology research centers, school enterprise cooperation, and promoting transformation of scientific and technological achievements into productive forces.

First, improving the teaching practice base is helpful to enrich the practical teaching of colleges and universities, and improve the students' professional skills and practical application ability. Universities and enterprises, scientific research institutes have signed agreements on talent cultivation, scientific research, achievement transformation, production and operation, etc., to determine responsibilities and rights of all parties, and jointly build and operate. Second, schools and enterprises jointly build laboratories. On the one hand, they help universities to improve their practical ability and comprehensive ability. On the other hand, they help enterprises to transform scientific and technological achievements into productive forces through laboratory platforms. Third, school enterprise cooperation to establish engineering technology research center. Common colleges and enterprises in consultation, according to their respective needs, construction and operation, through in-depth study and exploration of the research project, major scientific research achievement, create economic benefits and social benefits for society and enterprises at the same time, the university teachers in scientific research work in learning exercise, and enhance scientific literacy level, and promote the teaching work and the cultivation of talents. Fourth, promote the transformation of scientific and technological achievements into productive forces. Close contact and cooperation between universities and enterprises, can effectively promote the efficiency of scientific research, through scientific research achievements into productive forces, not only to university technology shares way into production and sales into the enterprise, obtain economic benefits, increase funding for education, at the same time, also help enterprises to reduce development costs, accelerate product development and improve the conversion rate of achievement

\section{OPTIMIZING TEACHING CONTENT AND CURRICULUM SYSTEM TO INNOVATE TRAINING MODE OF APPLIED TALENTS}

Colleges and universities should be based on the development needs of the transformation and upgrading of industrial structure, adjust the teaching content of disciplines, set fit industry, job requirements and curriculum system, strengthen cooperation, strengthen the close cooperation between universities and enterprises, reform education mode, training mode of flexible talent training, deepening order orientation training to improve training posts. The quality of applied talents.

\section{A. Optimizing teaching content and curriculum system}

Colleges and universities should combine their industrial transformation and upgrading and structural adjustment, take full consideration of their own real resources and development plan, and formulate the training plan and training mode of applied talents. In order to serve the development of the local area, we should adjust the disciplines and disciplines, set up teaching contents that fit the needs of the industry and jobs according to the needs of local economic development, industrial structure transformation, upgrading and development

Based on the optimization of teaching content, reasonable planning applied curriculum system, not only pay attention to the students' basic theory knowledge, also want to pay attention to broaden the students' knowledge of related disciplines, on the other hand, to both the theoretical teaching and practical teaching, avoid the theory and practice of light weight, teaching hours, teaching practice in science credits the proportion of students, strengthen the system of skill training, give full play to the education function of practice teaching in applied talents training, and effectively improve the students' practical ability, ability to solve problems and comprehensive application ability. 


\section{B. The training mode of innovative talents}

Colleges and universities should strengthen the cooperation between school and enterprise in the background of industrial transformation and upgrading. We should strengthen the close cooperative relationship between universities and enterprises, and create a mode of educating people dominated by employment. Through the school enterprise cooperation, we should avoid the teaching mode of University as the main body of teaching, and make universities and enterprises become the two main bodies of applied talents training. We should adopt flexible and diverse cooperation modes to improve the fit degree between school education and post occupations, and improve the quality of Applied Talents Training. The training mode of applied talents generally includes the following. First, order training mode, enterprises of colleges and Universities Based on tailored skills specifications and quantity demand, and enterprise cooperation, jointly develop training programs, teaching materials, classroom teaching and practice training, guidance, and establish collaborative student assessment standards, to enhance the cultivation of applied talents docking and occupation, promote appropriate the application of talents cultivation. Secondly, orienteering multi - post training mode. The main feature of this mode is that universities and a number of cooperative enterprises jointly formulate talent training mode, training specifications and standards, updating teaching and training talents can adapt to several jobs similar to those that they are studying. This not only improves the efficiency of the training of applied talents, but also widens the employment level of the graduates.

\section{STRENGTHENING THE TRAINING OF "DOUBLE-QUALITY TEACHERS" AND BUILDING A COMBINATION OF TEACHING TEAM}

The construction of teachers is an important guarantee of cultivating talents in Colleges and universities, colleges and universities is a difficult problem urgently to be solved, in order to meet the demand for the industrial transformation and upgrading, to achieve the sustainable development of colleges and universities, colleges and universities should strengthen the training of " double-quality teachers " construction, professional and excellent teaching combined with the school team, optimize the source of Teachers

\section{A. Improving the training mechanism of "double-quality teachers"}

The training of "double-quality teachers" in Colleges and universities can be carried out in the following ways. First of all, the establishment of incentive mechanism of " doublequality teachers " inter school exchanges, overseas training and academic exchanges, enhance the enthusiasm and initiative of teachers learning; secondly, we set up a subsidy mechanism of enterprises, to provide opportunities for learning and practice of teachers post enterprises issued reasonable subsidies, the relevant personnel incentive " double-quality teachers " and the enterprise each part, mobilize the enthusiasm of enterprises in the double-quality teachers in training, to further promote cooperation in the double-quality teachers training in the role of.

\section{B. Building a "double-quality teachers" incentive mechanism}

The "double-quality teachers" incentive mechanism, such as commendation and reward, not only guarantees the spiritual reward of the "double-quality teachers", but also includes material and other rewards. The incentive mechanism and measures to urge teachers to improve teaching quality through the system also includes encouraging teachers to obtain the corresponding reasonable return on technology transfer, patent licensing and technical services and a series of ways, at the same time in the " double-quality teachers " evaluation, awards and project reporting and other aspects of preferential policies. In addition, to encourage the " double-quality teachers " knowledge, capital, technology, management and other elements involved in the school and enjoy the reasonable power, which is extremely important, contribute to the formation of more full-time teachers and technical personnel in the industry enterprises jointly participate actively in application oriented universities, forming a special combination of the teaching team, improve the quality of training applied talent.

\section{STRENGTHENING THE EXPLORATION OF TEACHING MANAGEMENT INNOVATION AND IMPROVING THE TEACHING QUALITY GUARANTEE SYSTEM}

By strengthening the construction of teaching management team, explore the management innovation strong teaching to strengthen the study of teaching management and other measures to improve the teaching quality guarantee system, the establishment of school two level teaching supervision group, at the beginning of the period, in the end, the implementation of conventional teaching inspection system, pay attention to students' information feedback system, leadership system normalization methods such as lectures, teaching the normalization of quality control.

\section{CONCLUSIONS}

To upgrade the regional economic development and industrial restructuring, promote the development of industrial development and the interaction between the increasingly close, the implementation of the strategic upgrading of the industrial transformation of Shandong, provides new opportunities and challenges for the cultivation of Applied Talents in Colleges and universities in Shandong, from relying on the industry development, the whole layout of the transfer of professional disciplines; on the basis of the demand for the industrial transformation and upgrade sound, the integration of production and education mechanism; optimize the teaching content and curriculum system, training mode of innovative applied talents; strengthen the "double" training quality of teachers, construction of teaching team with professional and management innovation; strengthen the teaching, improve the teaching quality guarantee system and puts forward the countermeasures to cultivate applied talents in Colleges and universities. 


\section{ACKNOWLEDGMENT}

The general project of the Shandong soft science research program: Research on the dilemma and countermeasures of application-oriented talent cultivation in Shandong colleges and universities under the background of industrial transformation and upgrading (2017RKB01261).

\section{REFERENCES}

[1] Bie Dunrong, Qi Tianyu. First-class foreign universities undergraduate teaching reform and construction trend of $[\mathrm{J}]$. China higher education research, 2016, (07).

[2] Wang Fang. Training of Applied Talents in Colleges and Universities Based on the supply side reform [J]. Jiangsu high education, 2016, (05).

[3] Hou Changlin, Luo Jing, ye Dan. [J]. Education Research on the orientation of new universities under applied university, 2015, (04).

[4] Liu Dong, Wang Hui. The comprehensive revitalization of the integration process of the school enterprise of the American Community College [J]. China Vocational and technical education, 2015, (03).

[5] Wu Zhongjiang, Huang Chengliang. The intension of applied talents and the training of Applied Undergraduate Talents [J]. Higher engineering education research, 2014, (02). 